\title{
BiR KAMU KURULUŞUNUN ÜST düZEY YöNETicileRINiN iş STRESi VE KişiLiK ÖZELLIKLERi
}

\author{
Doc. Dr. Aliye Mavili Aktaş \\ Hacettepe Üniversitesi \\ Sosyal Hizmetler Yüksekokulu
}

\section{Özet}

Bu çalş̧mada bir kamu kuruluşundaki üst düzey yöneticilerin iş stresi ve kişilik özellikleri değerlendirilmiştir. Yeniden yapulanma, yasal değişiklikler, ekonomik sorunlar ülkemizin içinde bulunduğu koşullardandır. Bu koşullar, hem kamu kesimi, hem de özel kesim çalı̧anlarının iş stresini olumsuz yönde etkilemektedir. Üst düzcy yöneticilerin rekabetçilik, atılganlık gibi, kişilik özellikleri gösterdiği literatürde sukça vurgulanmaktadır. Bu amaçla, kamu kesiminde çahı̧̧an üst düzey yöneticilerin iş streslerinin ve kişilik özelliklerinin nasıl bir profil sergilediği incelenmiştir.

Araşturma örnekleminin büyük bir bülümünün $\Lambda$ tipi kişilik özelliği gösterip, yüksek i̧̧ stresi düzeyinde olduğu görülmüştür. Bu sonuçlar beklentilerimize uygun bir bulgudur. Araştırmada kişilik özelliği ile stres düzeyi arasında da istatistiki açıdan anlaml bir ilişki bulunmuştur.

\section{Stress Levels and Characteristics of Personalities of Top Level Managers of the Government Sector \\ Abstract}

In this study, stress levels and characteristics of personality of top-level managers, in the government sector, have been investigated. Restructuring, act changes and economic problems are the most typical aspects of our country. These conditions increase the stress level of employees of both the government, and private sector. The fact that top level managers show such characteristics as competitiveness, assertiveness, etc.. has been emphasized very frequently in the literature. With this airn, what sort of profile the top managers of the government sector demonstrate, has been researched.

It has been found that out the greatest percentage of the rescarch sample has "A type personality" characteristic and a high level of job stress. These findings are in line with our expectations. A statistically significant relationship has been found between personality characteristics and job stress level in this study. 


\section{Bir Kamu Kuruluşunun Üst Düzey Yöneticilerinin İş Stresi ve Kişilik Özellikleri}

Çalışma yaşamı pek çok stres kaynağının bulunduğu bir ortamdır. Işyerlerinde yaşanan stresin toplumsal koşullarla ilgili boyutlan olduğu kadar, işin kendisinden kaynaklanan boyutları da vardır. Is yerlerinde gerek sosyal gerekse işe özgü boyutların bütün çalışanlar üzerinde aynı etkiyi yapması da düşündürücüdür. Aynı işyerinde çalışanların bir bölümü benzer koşullardan daha az etkilenirken bir bölümü de daha fazla olumsuz etkilenebilir. Bu durum da stresle ilgili geniş toplumsal koşullara, organizasyon ya da kurumla ilgili boyutlara bireyin başetme potansiyeli ya da toleransı da katıldığında konunun çok boyutluluğu dikkati çekmektedir.

Eğer bir işyerindeki koşullar, çalışanlar üzerinde doyumsuzluk yaratan bir etkiye sahipse, çalışanlann fiziksel ve ruhsal durumu olumsuz yönde etkilenir. Bu durum, çalışanların kendisini olumsuz algılamasına, olumsuz iş davranışlarında bulunmasına ve kurumdan yararlananlara olumsuz duygular hissetmesine neden olur.

Günümüzde stresle ilgili çalışmaların yaygınlaşmasına karşılık (AKTAŞ / AKTAŞ, 1992) stres yaşatan faktörlerin çeşitliliği ve değişkenliğinin göz önünde bulundurulması gerektiğini söyleyebiliriz. Söz gelimi, savaşlar doğal afetler ya da ekonomik kriz dönemlerinde siyasal olaylarda toplumun bütününe yansımış bir stres ve kaygıdan söz ederken, olumsuz çalışma şartlan ücret ve terfi sistemi gibi kurumun örgütsel yapısından kaynaklanan boyutların da etkili olduğunu biliyoruz.

Bu arada stresin bireyi motive eden ve harekete geçiren olumlu bir özelliğinin de olduğunu söylcyebiliriz. Ancak stresin bu olumlu yan onun derecesi ve düzeyiyle ilgilidir. Belli bir orandaki stres bireyi hazırlanmaya ve daha yeterli hale getirmeye yöneltir. Söz gelimi, sınavlar sırasında bireyin kaygısı onu daha çok çalışmaya, okumaya ve öğrenmeye yöneltir. Ancak bunun düzeyinin artması durumunda da başansızlıklar ve ketlenme görülebilir. Azının yararlı olduğu böylesi bir durumun ne düzeydekinin yararlı olabileceği konusu ise hala tartışılmaktadır (AKTAŞ / AKTAŞ, 1992). 


\section{Stresin Tanımı}

Çalışanlar ve kurumlar üzerinde olumlu ve olumsuz etkilere neden olan stres, konuyla ilgili yapılan çalışmalarda şu şekillerde tanımlanmaktadır.

Stres, organizmanun çevreyle olan etkileşimidir. (IVANCEVICH / MATTERSON, 1980 aktaran AKTAS / AKTAŞ, 1992). Aynu yazarlar stresi, kişi üzerinde özel fiziksel veya psikolojik talepler yaratan herhangi bir dış faaliyet, durum veya olay sonucu olan ve kişisel nitelikler veya psikolojik süreçlerle ortaya çıan bir uyum tepkisi olarak da tanımlamaktadırlar (Aktaran AKTAS / AKTAŞ, 1992).

Stresin kişi ile çevresi arasındaki etkileşimden doğan bir durum olarak tanımlandığı da görülmektedir. (BEEHR / NEWMAN, 1978 akt. AKTAS / AKTAŞ, 1992). Aynu kişiler iş stresini de, kişilerde meydana gelen ve onlan normal faaliyetlerden sapmaya zorlayan değişik bir durum olarak ifade etmektedir.

SELYE'ye göre (1974) stres, herşeyden önce bireyde bir enerji tükenmesine yol açmaktadır. Gerçekte strese uyum için kullanulan enerji kaynaklan tükenebilir niteliktedir. Canlılara zarar verici özelliğiyle stres bedende yıpranma ve yaşlanmaya yol açmaktadır. Stresin olumlu ve olumsuz özellikleri SELYE (1974) tarafından da vurgulanmaktadır. Bu yüzden, stres, kurum çalışanlarının işlev ve performanslann olumlu yönde etkilerse "olumlu stres", hastalık yapıcı veya zararh bir şekilde etkilerse "olumsuz stres" olarak da adlandırılabilmektedir (QUICK / OUICK, 1984: 3).

Yukarıda ele alınan tanımlar ışığında stresin genel özellikleri şu şekilde suralanabilir:

1. Stres çok yönlü bir olgudur. Stresin olumsuz özellikleri olsa da olumlu katkıları da vardır. Çalışanlann performansın düşürdüğü gibi artırdığı durumlar da söz konusudur. Bu arada stresin psikolojik, fizyolojik ve sosyal yönlerinin neden ve sonuçları göz önünde bulundurulmalıdır. Stresin temel yapısı istekler, tepkiler ve sonuçlar örüntüsü içinde anlaşılabilir.

2. Stres, çoğunlukla kaçınılmaz bir durumdur. Çalışan kişinin içinde bulunduğu sosyal çevre, aile ilişkileri, çalışılan kurumun örgüt yapısı, işin kendisi, çalışma arkadaşları, amirleri, astları, toplumdaki hayat tarzı, sıcaklık, aydınlatma, gürültü, amaçlara ulaşamama, karar verememe v.b. birçok koşul çalışan bireyi sıkıntıya düşüren stres faktörleridir. Bu olumsuz koşullara ek olarak kimi olumlu koşullar da (başarlı olmak, ödül kazanmak, okul bitirmek, mezuniyet v.b) strese neden olabilmektedir. Bu nedenle toplum içinde yaşamak, yaşamı paylaşmak kendi başına birçok kişi için stres kaynağıdır. 
3. Stres, bireyin ulaşmak istediği aşamalar ve bu alanda karşılaştı̆̆ kısıtlamalarla ilgilidir. Istekler, arzulanan bazı şeylerin kaybedilmesine neden olurken, kısıtlamalar kişiyi arzulanan şeyleri yapmaktan alıkoymaktadır. Kişinin elde edeceği başarı, yükselmeyi, daha fazla sorumluluk üstlenmeyi ve iş yaşamında daha yüksek ücret almayı sağlar. Başarısızlık ise, bunların tersine işten atılmaya neden olabilir. Ancak bu noktada neye başarısızlık dendiği ya da neyin başarısızlık olarak tanumlandığı da önemlidir. Birey ya da çalışan kendisinin başansızlık olarak alglamadığı bir sonucun, sistem tarafından başansızlık olarak adlandırılmasıyla karşılaştğında daha ciddi bir stres faktörüyle karşı karşıya kalabilir.

4. Stres, örgütsel başarı ve performansı etkileyen önemli faktörlerden birisidir. Gerek kamu, gerekse özel sektörün her kademesinde görev yapanlar için stres, iş yerindeki faaliyetlerin etkili biçimde yerine getirilmesini olumsuz yönde etkiler.

5. Stres, çalışanları ve çalışmayanları hem psikolojik hem de fizyolojik yönden etkiler. Stres altunda kalan bireyler, kendi bireysel özelliklerine göre farkhı tepkiler gösterebilirler. Bu tepkiler, yorgunluk, kızgınlık, saldurganlık gibi tepkiler olabileceği gibi, fazla yemek, içmek ya da iştahsızlık gibi bozukluklara yol açabilir'(ARNOLD vd, 1986 aktaran IŞIKHAN, 1998). Bireydeki yoğun üzüntüler, başağrisı ve depresyona yol açtı̆̆ı gibi bedenin direncini düşürdüğünden birçok virütük rahatsızlığa neden olabilir.

Is ortamında stres yaratan faktörlerin oluşumunu tam olarak anlayabilmek için, stresten etkilenen bireyler için halihazırdaki işlerinin ne ifade ettiğini bilmek gerekir. Kişinin statüsü ve pozisyonu yükseldiğinde işin getirdiği sorumluluklarla birlikte ödüllendirici fonksiyonun da arttğını söyleyebiliriz. Bu nedenle iş ortamı ve işi kişinin duygusal alanunda da olumlu bir yer tutabilir. Toplumsal ortam ve koşullar işi ve bu işe yüklenen prestijde olumsuz bir yükleme gerektiğinde, benzer konumdaki bütün bireyler veya çalışanların stres düzeyinin de yükseldiğini söyleyebiliriz. Söz gelimi, medyada herhangi bir meslek grubuyla ilgili olumsuz bir haber, toplumun o meslekle ilgili tutumlann olumsuz olarak etkilediğinden bu dönemde bu meslek grubunun stresi artmaktadır. Çalışma hayatında "stres kavramı," kişinin kendisini rahatsız hissettiği ve performansınun normalden aşağıda ya da çok yukarıda olduğu psikolojik bir durum olarak değerlendirilmektedir (BERKHAUT, 1980: 407).

\section{Stresin Oluşum Nedenleri}

Stresin nedenleri, kurumların içinden, dışından, gruplardan ve bizzat çalışanların kendilerinden kaynaklanabilir. Kurum açısından stres, yaşamın 
önemli bir bölümünü (8-10 saat) iş yerinde geçiren bireyin içinde bulunduğu durumu anlatmak için kullandı̆̆ı, daha çok duygusal, öznel öğeler ve deneyimlerle yüklü bir kavramdır. Kurumlar büyüyüp, karmaşık hale dönüştüğünde çalışanları etkileyen stres faktörleri de giderek artmakta hatta belirsizleşebilmektedir.

Iş ortamlarının makro düzeydeki stres faktörleri arasında, politikalar (adil olamayan başarı değerlendirmeleri, ücretlerdeki eşitsizlikler), kurumun yapısı ve özellikleri (merkeziyetçilik, terfi için tanınan fırsatların azlığı) fiziki şartlar (kalabalık, aşırı gürültü, sıcak ve soğuk yerde çalışma) ve kurumsal süreçler (çalışanlar arasındaki zayıf iletişim, dengesiz ve adaletli olmayan bir kontrol sistemi) v.b. sayılabilir (IŞIKHAN, 1998:10).

Kurum dışı ve kurumla ilgili grup stres faktörleri (uyuşmazlık, çatışma, düşmanca duygular ve davranışlar) birey üzerinde olumsuz yönde etkilidir. Literatürde bircyi etkileyen stres faktörleriyle ilgili çok sayıda araştırma bulunmaktadır. Bu çalişmalardan elde edilen bilgilere göre kişisel stres faktörlerinden rolle ilgili olanlar arasında uyuşmazhk, belirsizlik, aşın veya az iş yükü ile yaşam ve kariyer değişikliklerinden eşin ölümü, yaşlanma, emeklilik gibi durumlar da strese neden olur. Işin kendisinden kaynaklanan stres, bireyin fiziksel, duygusal ve sosyal davranışlarını ve kurumla olan ilişkilerini yakından etkileyebilmektedir (AKTAŞ / AKTAŞ, 1992: 156-159).

Yapılan işin niteliği, zorluk derecesi ile kişisel durum değişkenleri hem stresin düzeyini hem de işteki başanyı olumsuz yönde etkilemektedir. Yüksek düzeydeki strese bağlı olarak, yüksek kan basıncı, ülser, kalp hastalıkları hatta kanser gibi fiziksel sorunlar ile sinirlilik endişe depresyon ve sıkınt, kendine güvenin azalması, karar verme ve dikkati toplamada yetersizlik, is doyumsuzluğu gibi psikolojik sorunlar ortaya çkabilir (MC GRATH, 1976 aktaran AKTAS / AKTAŞ, 1992). Stresin bu fiziksel ve psikolojik sorunlan ve davranıssal š̉onuçlan kontrol edilebilir ve etkili bir şekilde yönetilebilir, hatta kişi ve kurum tarafından ortadan kaldırılabilir. Kurumlar çalışanlarının stres düzeylerini tespit ettikten sonra bunu ortaya çıkaran nedenleri düzeltici ve ortadan kaldırıcı önlemler alamazsa o alanda yetişmiş, deneyimli ve bilgili birçok değerli kişinin görevden ayrılmasına (turnover), işe gelmemesine (absenteresim) ve iş verimliliğinin düşmesi gibi olumsuz sonuçların ortaya çlkmasına neden olabilir. Bu durum hem kurumlar hem de toplumun bütünü açısından nitelikli insan gücünün kaybı, hatta sistemin değerli unsurlarının çökmesi anlamına gelir.

\section{Stresin Çalışan Üzerindeki Etkileri}

Stres konusunda çalışma yapanlar, stresin kurum ve toplum üzerindeki olumsuz etkileri kadar çalışan üzerindeki etkilerini de sorgulamışlardır (SELYE, 
1974 aktaran AKTAŞ / AKTAŞ, 1991). Selye stresin bireyler üzerindeki etkisini "genel uyum sendromu" kavramlaşturması ile ele almaktadır. Bu kavramlaştrrmada stresin birey üzerindeki etkisi ǚ aşamada gerçekleşir. Bunlar alarm, direnme ve tükenmedir. Alarm aşamast; stresin birey tarafından alglandığ ilk döneme işaret eder. Bu aşamada stresi alglayan bireyde fizyolojik bir takım değişiklikler olur. Göz bebekleri büyür, yüz solar, kalp atşlan huzlanır, damarlar büzülür, kan şekeri yükselir, midenin asit salgılaması artar. Kişi istenmeyen koşuldan ya kaçar ya da mücadele eder. Kişinin mücadeleden çekinerek bu durumu yok sayması da bir tepki biçimidir. Stresin devam etmesi durumunda direnme sürecine girilir. Direnme aşamasi; stres verici koşullara uyum sağlamak üzere direncin gelişmesi durumudur. Bu dönemde birey stresi belki de yenebilir. Stresi yenemeyen birey, yoğun ve sürekli gerilimiyle bünyesinin savunmasın zayflatabilir ve tükenme aşamasına geçebilir. Tükenme aşaması; hayatı çekilmez olarak görüldüğü bir aşamadır. Uykusuzluk, canlılı̆̆ın yitirme, baş ve göğüs ağrıları, öfke patlamalan, kızgınlık, yalnuzlık, çaresizlik, şüphecilik, engellenmişlik, cesaretsizlik ve can sikıntısı görülür. Stresin uzun süreli olması, bedenin kapasitesini ve savunmasını tahrik edebilir. Selye, stresin aşıısının yaşam süresini kısalttı̆ı̆ı da vurgular. Stresle ilgili son yllardaki çalışmalarda da tükenmişlik sıklikla vurgulanmaktadır (ARCHES, 1991). Tükenmişlik çalışma motivasyonunun azalması, benlik saygısında azalma, empati yapamama, kişiler arası ilişkilerde kurallara uymama, işte yoğunlaşmada güçük çekme, sosyal izolasyon, yorgunluk, cinsel ilginin azalması uyku bozuklukları, sigara ve alkol kullanımında artmanın görüldüğü bir durumdur. Arches (1991) tükenmişlik dönemini coşku dönemi, durgunluk dönemi, engellenme dönemi ve apati dönemi olarak kavramlaştırmıştır. Bu çerçevede tek başına tükenmişlik döneminin aşamaları arasında da farkhlıklar görülebilir.

Günlük hayatın bir parçası olarak değerlendirilen stres yeni bir olgu değildir. Kurumsallaşma ve sanayileşme, çalışanların hem bedensel hem psikolojik yönden etkilenecekleri koşullar yaratmaktadır. Bu şartların sürekliliği de bireylerin kalıcı bozukluklar ve uyum sorunları yaşamasına neden olur.

Stresin kişilerde çeşitli sorunlar yaratmasına ek olarak kişilik özelliklerinin de stres kaynağı olabildiğini söyleyebiliriz.

\section{Stres ve Kişilik Ōzelliği}

Bireyin kişilik özelliğinin stres kaynağı olduğu da bazı araştırmalarda vurgulanmaktadır (ROSENMAN / FRIEDMAN, 1974 aktaran ARIKAN / AKTAŞ,1988). Çalışmalanında kişilikleri A ve B tipi olarak sınıflayan Friedman ve Rosenman bu kişiliklerin özelliklerini de sıralamıştr. 
A tipi kişilik özelliği: Yükselme, başan hırsı, başkalanyla yarışmak, heyecanlılık, duygusallık, acelecilik, zamana karşı yarışmak, saldırganlık, işleri hemen bitirme eğilimi, işlere aşırı bağhlık, hareket ve konuşmanun huzh olması, çabuk öfkelenmek, sabırsızlık, insan ilişkilerindeki zayıflık, dinlenmeyi sevmemck, kişisel ve sosyal yaşantyya zaman ayırmamak, planlamayı zaman kaybi olarak görmek, kuyrukta beklemekten sıkılmak, başkasının sözünü kesmek, yerinde duramamak ve otururken sürekli ayaklanı oynatmak gibi birçok özelliği gösterir. A tipi kişilik özelliği gösteren kişilerde bu özelliklerin birçoğu birarada bulunabilir. Bu çerçevede bu tip kişilerin kanındaki kolestrol oranının yüksekliğine bağlı olarak kalp krizi geçirme riskinin yüksekliğinden de bahsedilebilir (ARIKAN / AKTAŞ, 1988). Kurumlar ve işletmeler sıklıkla A tipi kişilik özelliğine sahip kişileri tercih edebilirler. Çünkü verimlidirler ancak uzun dönemde çabuk yıpranırlar.

B tipi kişilik özelliği; bu kişiler işleriyle ilgili olarak oldukça rahat davranırlar. Zaman ve başan ile ilgilenmemek, işte kalite aramak, başkalarıyla yarışmamak, kendisinden emin, sağlığına düşkün ve boş vakti bol olmak, herşeyi olduğu gibi kabul etmek, herkesle dostluk içinde olmak, çevreye açı ve sosyal yaşamı seven bir özellik taşımak temel özelliklerdendir. B tipi kişilik özelliği gösteren kişilerin bazı zararlı alışkanlıklan (sigara, alkol v.b.), ya da kalıtsal kalp problemleri olsa bile daha sağlıklı kişiler olarak da adlandırılabilir. Bu kişiler stresin etkisinden de kolayca kurtulabilirler.

KÖSE (1985) orta düzey yöneticilerle yaptı̆ı araştırmada, stres ile kişilik özelliği arasında anlamlı bir ilişki olmadığın bulmuştur.

Burada üzerinde durulması gerekli olan nokta, stres faktörleri ile kişilik özelliği arasındaki karşılıklı ilişkinin oldukça karmaşık boyutudur. Acaba A tipi kişilik özelliği bireyler iş streslerini daha yoğun mu algillyor? Yoksa iş stresi faktörleri mi, onların A tipi özelliğini belirginleştiriyor?

Görüldüğü gibi stres çok yönlü ve boyutlu bir durumdur. Bu konu ile ilgili pek çok kavramlaştırmadan daha önceki bölümlerde bahsedildi. Ancak bu çalışmada kullanılan ölçüm araçlarıyla ilişkisi açsından Copper ve Marshall'ın Iş Stresi Modeli'nden de söz etmek yerinde olacaktır. 
Tablo 1-Cooper ve Marshall' in Is Stresi Modeli

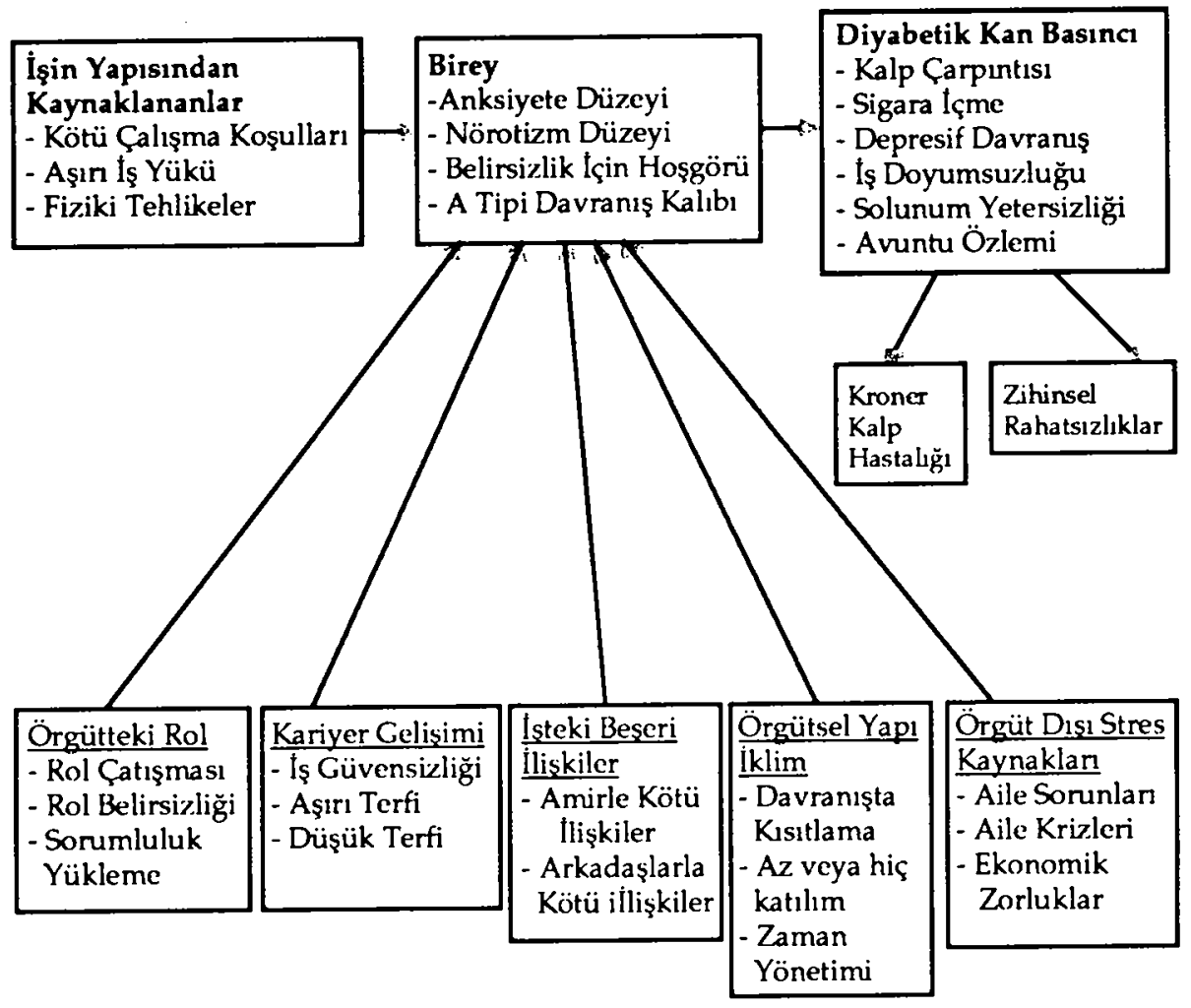

Kaynak: (COOPER /MARSHALL, 1976 aktaran GÖDELEK, 1988:55)

Bu modelde de iş stresinin belirlemesinde kişinin özellikleri ile iş çevresinin durağan kaynaklannun birbirleriyle olan etkileşiminin önemli bir yer tuttuğu belirtilmiştir. Bu arada örgüt dişı değişkenlerin de (aile sorunlan, aile krizleri, v.b) bireyin stresi ile ilişkisi vardır. Bu çerçevede başlangıç bölümünde de vurgulandığı gibi bireysel, çevresel, kurumsal (örgütsel) düzeyde birçok değişkenin aynı olguya (strese) birlikte etki etmesi söz konusudur. Bu birlikte etkide hangilerinin daha önemli olduğu konusunda kesin bir kanya ulaşmak güçtür. Çünkü genel çevresel koşullara (olumsuz bile olsa) daha toleranslı davranılırken, bireysel koşullardaki değişmede aynı koşullara daha az toleranslı davranmayı gündeme getirebilir. Bu nedenle belli değişkenleri kontrol altında tutarak yapılan değerlendirmelerde sonuçlarda bu değişkenlerin etkisi ya da önemliliğini belirlemek zaman zaman zordur.

Bu noktada Hackman ve Oldham'da işgörenlerin psikolojik açıdan işten etkilenme boyutların üç ana başlık altında ele almıştır (HACKMAN / 
OLDHAM, 1976 aktaran EROL, 1988). Bu üç boyut: 1-Işgörenin işini önemli bulması, 2-Işin sonuçlan hakkında sorumluluk duygusu geliştirmesi 3-Sonuçların bilmesi. Bu süreç iş algısına sahip çalı̧̧anlann motivasyon düzeyini belirlemektedir ve bu algının işgücü devri, devamsızlık ve iş doyumu ile yakın ilişki içinde olduğu ifade edilmektedir.

Görüldüğü gibi, literatür, iş stresinin kurumsal koşullar ve bireysel faktörlerle ilişkisi konusunda zengin bir bilgi birikimine sahiptir. Konu ile ilgili bu denli çalışmanın olması bu alanda yeni çalışmaların farklı ortamlarda ve yeni sosyal koşullarda da sik sik tekrarlanmasın gündeme getirmektedir. Herşeyden önce, iş yaşamı sıklıkla insanun yaşam doyumu ve mutluluğunu etkileyecek kadar önemli bir alandır. lçinde yaşadığımız ekonomik sorunlar ve yapısal reformlar kamu kesiminde de, özel sektörde de çalışanların stres faktörlerini arturan bir etki yapmaktadır. Bu koşulların kronikleşmesi iş stresinin artarak devam etmesine de neden olabilir. Bu çerçevede iş yaşamında yapılacak çalışmalardan elde edilecek sonuçların, destek hizmetlerinin yerinde ve zamanında verilebilmesini sağlayacaktır.

\section{YÖNTEM}

Bu küçük çalışmada 81 üst düzey kamu yöneticisinin iş stresi ve kişilik özellikleri değerlendirilmiştir.

Çalı̧̧mada kullanılan I̧̧ Stresi Ölçeği (Bknz: EK-A), Dr. Suzanne Haynes tarafından Ulusal Sağlık Istatistikleri Merkezi'nde çalışan kadınlar ve erkekler üzerinde uygulanmış ayn ölçck AKTAŞ (1996) tarafından Türkçe'ye uyarlanarak güvenilirlik çalışması gerçekleştirilmiştir. Ölçeğin uyarlama çalışmasında uzman grubundan yararlanılmıştır.

Ölçeğin güvenirliği ile ilgili çalışma iki farklı ancak benzer amacı olan analiz ile gerçekleştirilmiştir. Güvenilirlik çalışmasında bütün soruların birbiriyle ilişki düzeyi (Alpha $r \leq=0.8789$ ) bulunmuştur (AKTAŞ, 1996). Bilindiği gibi Cronbach's Alpha kullanılan ölçeğin iç tutarılığınu yansıtmaktadır. Bu test ile ölçeğin soruları arasındaki ortalama korelasyona bakılmıştır. Ölçek Ankara'da 100 'den fazla iş̧̧i çalıştıran 40 işyeri sahibine 15 gün arayla uygulanmıştur. Ön test sonucu (alpha: 9239) son test sonucu (alpha:9347) olarak belirlenmiştir. Ölçeğin son test uygulamasında katsayının yükselmiş olması, güvenirlilik açısından olumlu bir sonuç olarak değerlendirmektedir.

Ölçekle ilgili ikinci analiz de split half testidir. Bu analizde ayn amaca hizmet etmektedir. Burada ölçeğin sorulan iki gruba aynlmış ve bu iki grup soru arasındaki korelasyona bakılmıştır. Test sonucunda l'e yakın bir değer 9273 ģkth̆ 1 için güvenilir bulunmuştur (AKTAŞ, 1996-2001). Testin kamu kesiminde üst düzey yöneticiler üzerindeki yeni uygulamasında da kişilik 
özellikleri ile stres düzeyi arasındaki ilişki araşturlmıştur. Stres ölçeğinde 12'den düşük puan düşük stresi $12-30$ ve 30 'dan büyük puan ise stresli ve yüksek stresli durumu ifade etmektedir.

Kişilik Özelliği Tarama Testi (Bknz: EK-B) 7 sorudan oluşan likert tipi (8 dereceli) bir ölçektir. ${ }^{1}$ Bu test kişilik tipini belirlemeyi amaçlamaktadır. Literatürde A tipi kişilik ile stres arasında önemli ilişkiler olduğu üzerinde durulmaktadır (AKTAS / AKTAŞ, 1992). Ölçekte yüksek puan A tipi kişilik özelliğini göstermektedir. Ölçek sonucu elde edilen toplam puan 3 ile çarpılarak değerlendirme yapılmaktadır (En yüksek puan 168 en düşük puan 21 'dir). Puanlar $100^{\prime}$ den fazla ise A tipi kişilik, $100^{\prime}$ den az ise B tipi kişilik olduğuna hükmedilir.

Daha öncede belirtildiği gibi bu çalışma bir kamu kuruluşunda ${ }^{2}$ gerçekleştirilmiştir. Kamu kuruluşunda üst düzey yöneticilere hizmet içi eğitim programıyla destek hizmeti verilmiştir. ${ }^{3}$ Bu amaçla, hizmet içi eğitim programındaki sorumluluğumuz çerçevesinde öncelikli olarak bir durum tespiti yapılmak istenmiş ve bu çalışmada kullanılan iki envanter ile (stres ölçeği ve kişilik özelliği tarama listesi) üst düzey yöneticilerin stres düzeyi ve kişilik özelliği ölçülmüştür.

Araşturma kapsamındaki üst düzey yöneticilerin büyük bir bölümü (5 kişi) 41-51 yaş grubundadır. 30-40 yaş grubunda 16 kişi bulunurken 13 kişi de 52-62 yaş grubundadır.

Araştırma grubundakilerin çoğunluğunun evlilik süresi oldukça uzun olup (76 kişi) 13 yıldan uzun süre evli olanlann sayısı 39 kişi, 22 ylldan uzun olanların sayısı ise 37 kişidir. Üst düzey yöneticilerin büyük bir bölümünün uzun süredir düzenli bir aile yaşamı vardır. Buna bağlı olarak da bu evliliklerin çoğunda çocuk bulunmaktadır.

1 Bu ölçek, Arkkan ve Aktaş (1988) tarafından kalp hastaları üzerinde uygulanmıştır. Araştırmada Friedman ve Rosenman tarafından geliştirilen kişilik envanteri kullanılmıştır. Bu çalışma 52 kalp hastası üzerinde kişilik özellikleri ve sosyo-ekonomik statü değişkenleri ile kalp hastalığının ilişkisi incelenmiştir (ARIKAN/ AKTAS, 1988: 725-726).

2 Bu çalışma hizmet örgütünde eğitim çalışmalan yapılırken gerçekleştirilmiştir. Söz konusu hizmet kuruluşuna bu sonuçlar hakkında bilgi verildiği için burada bu kuruluşun ismi verilmemiştir.

3 Ancak bu sonuçlann düzenli olarak izlenmesi gerekmektedir. Hizmet kuruluşlarının verimliliğinin sürekli gelişim ve destek hizmetlerinden yararlandığında arzu edilen sonuçlara ulaşabileceği göz önünde bulundurulmalıdır. Kamu kuruluşlannda tayin ve atanma yoluyla sık sık değişiklikler yapılması/ya da yapılmaması hizmet içi eğitim programlarının, geliştirici ve destekleyici projelerin etkililiğini tespit etmeyi güçleştirebilir. 


\section{BULGULAR}

Uzun süredir düzenli bir aile yaşamı içinde üst düzey yönetici olarak çalşan kamu görevlilerinin stres düzeylerinde kamu kesimindeki sık slk değişen yasal düzenlemeler ve sorumluluklar ile gelecekteki uygulamaların belirsizliğinin etkisi olacağı ileri sürülebilir. Bu tür koşulların sık sık değişmesi de onların A tipi kişilik özellik belirtilerini göstermelerine neden olabilir. Bu amaçla yaplan incelemenin sonucu Tablo (I) de sunulmaktadır. Örneklem grubunun kişilik özelliğini gösteren bu Tablo, örneklemin çok büyük bir bölümünün A tipi kişilik özelliği göstermesi açısından bu yöndeki kanılarımızı desteklemektedir. (\% 81.92) B tipi kişilik özelliği gösteren grubun oranının düşük olması, yöneticilerin kurum koşullarıyla ilgili algılarının ve bu doğrultudaki davranı̧ yönelimlerinin benzer olmasına neden olmuş olabilir.

TABLO I: Yōneticilerin Kişilik Ōzellikleri

\begin{tabular}{|c|c|c|}
\hline Yöneticilerin Kişilik Tipleri & Sayı & $\%$ \\
\hline A Tipi Kişilik & 68 & 81.92 \\
\hline B Tipi Kişilik & 15 & 19.08 \\
\hline TOPLAM & 83 & 100.00 \\
\hline
\end{tabular}

Öte yandan, beklenildiği gibi, örneklem grubunda yöneticilerin bir tanesi bile düşük stres düzeyinde bulunmamıştır. Bütün yöneticiler stresin varlığına işaret etmektedir. En düşük puanlı (18) 3 kişi olurken 80 kişi gibi tamamına yakın kısmı orta ve yüksek düzeyde stres algısına sahiptir. (Bkz. Tablo II). Yöneticilerin tamamına yakınınun benzer algıya sahip olması ve benzer davranış özelliklerini göstermesi, stres yaratan koşulların organizasyonla ilgili işleyiş, prosedürler ve uygulamada yaşananların ortak olduğunu düşündürmektedir. Bu çerçevede yöneticilerin bağh olduğu üst düzeydeki merkez teşkilatının daha sık işbirliği ve daha çok katılım konferanslarına yönelmesi gerektiğini düşündürtmektedir.

TABLO II: Yōneticilerin Stres Puanlan

\begin{tabular}{|c|c|c|}
\hline Stres Puanı & Say1 & $\%$ \\
\hline 12 'den az & 0 & 0 \\
\hline $12-30$ & 45 & 54.21 \\
\hline $30+$ & 38 & 45.79 \\
\hline TOPLAM & 83 & 100.00 \\
\hline
\end{tabular}


Araşturmada kişilik düzeyi ile stres düzeyi arasındaki ilişkiye de bakılmıştır. Tablo III de bu iki değişkene ait betimleyici istatistikler yer alırken Tablo IV de bu iki değişken arasındaki ilişki korelasyon analizi ile ortaya konulmaktadır. Tablo IV' de sergilenen kişilik düzeyi ile stres düzeyi arasındaki ilişkinin yüksekliği yukanda tanımlanan ortak kurum koşulların varlığını göstermektedir ( $r=0.347$ ve 0.001 düzeyinde istatistiksel açıdan anlamis). Bu sonuçlar ışı̆̆ında, içinde yaşanılan sosyal ekonomik koşulların üst düzey yöneticiler için (hem özel hem de kamu kesimindeki) stresli iş ortamı yarattı̆̆ ve yöneticilerin benzer davranı̧ özellikleri gösterdiği (A tipi kişilik) söylenebilir.

TABLO III: Kişilik Düzeyi the Stres Düzeyinin Ortalamalan Betimleyici Istatistikler

\begin{tabular}{|l|c|c|c|c|c|c|c|}
\hline & N & Minimum & Maksimum & Toplam & Ortalama & \multicolumn{1}{l|}{$\begin{array}{l}\text { Std. } \\
\text { Sapma }\end{array}$} & Varyans \\
\hline KISILIK DÜZEYI & 83 & 63.0 & 159.0 & 9480.0 & 114,217 & 23,434 & 549,172 \\
STRES & 83 & 18.0 & 39.0 & 2406.0 & 28,988 & 5,079 & 25,793 \\
Geçerli Gözlem \\
Sayı1sı
\end{tabular}

TABLO IV: Stres Düzeyi hle Kişilik Düzeyi Arasındaki hlişki

Correlations

\begin{tabular}{|cl|c|c|}
\hline & & YAS & KISILIK \\
\hline YAS & Pearson Correlation & 1,000 &, $314^{* *}$ \\
& Sig. (2-tailed) & $\cdot$ &, 005 \\
& $\mathrm{~N}$ & 79 & 77 \\
\hline KISILIK & Pearson Correlation &, $314^{* *}$ & 1,000 \\
& Sig. (2-tailed) &, 005 & $\cdot$ \\
$\mathrm{N}$ & 77 & 83 \\
\hline
\end{tabular}

** Correlation is significant at the 0.01 level (2-tailed).

Daha önce belirtildiği gibi üst düzey yöneticilerin büyük bir bölümü orta yaşın üzerindeki yöneticilerden oluşmaktadır. Bu doğrultuda yaş ile kişilik özellikleri arasındaki ilişki araştırılmış ve Tablo V'de sunulduğu gibi pozitif yönlü istatistiki açıdan önemli bir ilişki bulunmuştur (\% 0.5 düzeyinde). Bu bulgunun da beklentilerle uyum içerisinde olduğu görülmüştür. Bilindiği gibi 
ilerlemiş yaş belli davranıs değişiklikleri yapmada zor bir döneme işaret edebilir. Üst düzey yöneticilikte öğrenilmiş ve benimsenmiş tutum ve davranş̧lan değiştirmek daha da zorlaşabilir. Yöneticinin bu statüde kalı̧̧ süresi arttıkça davranş̧ değişikliği yaratmak daha da zorlaşabilmektedir.

TABLO V: Yaş he Kişilik Düzeyi Arasındaki hişki

Correlations

\begin{tabular}{|cl|c|c|}
\hline & & YAŞ & KISILIK \\
\hline YAS & Pearson Correlation & 1,000 &, $314^{* *}$ \\
& Sig. (2-tailed) & $\cdot$ &, 005 \\
$\mathrm{~N}$ & 79 & 77 \\
\hline KISILIK & Pearson Correlation &, $314^{* *}$ & 1,000 \\
& Sig. (2-tailed) &, 005 &. \\
$\mathrm{~N}$ & 77 & 83 \\
\hline
\end{tabular}

* Correlation is significant at the 0.01 level (2-tailed).

Öte yandan, Tablo VI' dan da görüldüğü gibi, araştırmada yaş ile stres arasında herhangi bir anlamlı ilişki bulunmamıştır.

TABLO VI: Yaş fle Stres Düzeyi Arasındaki hișki

Correlations

\begin{tabular}{|cl|c|c|}
\hline & YAŞ & KISILIK \\
\hline \multirow{2}{*}{ YAŞ } & Pearson Correlation & 1,000 &, 138 \\
& Sig. (2-tailed) & $\cdot$ &, 231 \\
$\mathrm{~N}$ & 79 & 77 \\
\hline \multirow{2}{*}{ KISILIK } & Pearson Correlation &, 138 & 1,000 \\
& Sig. (2-tailed) &, 231 &. \\
$\mathrm{~N}$ & 77 & 83 \\
\hline
\end{tabular}

\section{SONUC}

Mal ya da hizmet üreten organizasyonlarda uzun süreli yüksek stres koşullan çalışanların işteki verimliliğini ve genel sağhı̆ını olumsuz yönde etkilemektedir. Üst düzey yöneticilik, sorumluluk isteyen bir görev düzeyidir. 
Bu kademe yöneticilerin kişilik özelliklerinde belli davranuş kalıplan göstermelerine neden olmaktadır. Insana hizmet etme sorumluluğu olan kamu kuruluşlarında A tipi kişilik özelliği ve yüksek stres koşullarının hem çalışanlara hem de hizmetten yararlananlara olumsuz etkileri olabilmektedir.

Bu çerçevede kamu ve özel kesimde üst düzey yöneticilere yönelik gerçekleştirilecek hizmet içi eğitim programlarına A tipi davranı̧̧ özelliklerinin B tipi davranı̧ özelliklerine dönüşümü ve değişimi sağlanabilirse nitelikli insanların daha uzun süreli hizmet vermesi gerçekleştirilebilir. Bu da organizasyonların hem çalışanların hem de hizmetten yararlananların uzun dönemli memnuniyetini ve verimliliğini sağlayabilir. Yetişmiş nitelikli insanlar yeni gelişmelerden ve değişmelerden, hizmet içi eğitim, sürekli işbirliği ve iyileştirme programlan aracılığıyla istifade edebilirler. Bu çerçevede organizasyon içi düzenlemeler ve yeni program uygulamalarında organizasyonun her düzeyinde çalışanların katılımının ve işbirliğinin sağlanması oldukça önemlidir.

Nitekim bu çalışmadan elde edilen sonuçlar bu noktada çok olumlu olmasa da çalışma örneklemini teşkil eden gruba stresle başetme mekanizmaları hakkında aydınlatica konferanslar verilmiş ve sonuçta yöneticiler, çözümleyebildikleri sorunlar hakkında kaygı duymalarının daha sağlıklı olduğu kanısına ulaşmışlardır. Bunun yanında çözümleyemeyecekleri (ekonomik, iş değiştirme, gibi...) sorunlarla ilgili kaygılarınun rasyonel olmadığı noktasına gelmişlerdir. Bu sonuçların bile çalışmanın mütevazi hedefiyle ilgili olumlu bir gelişme olduğu düşünülmektedir. 


\section{EK-A}

\section{İ̧ STRES ÖLÇEĞİ}

Aşağıdaki sorulanı, şu anki işinizi göz önünde bulundurarak yantlayınız.

1- Şu anki iş yükünüzle ilgili duygunuz?

a) Beni çok fazla zorluyor ve bunaltıyor (5)

b) Beni çok bunaltıyor (4)

c) Beni zorluyor (3)

d) Beni biraz zorluyor (2)

e) Beni hiç bunaltmıyor (1)

2- Genellikle işten ayrılana kadar yapmanız gereken herşeyi bitirebiliyor musunuz?
a) Coğunlukla yapmam gereken herşeyi zamanında bitiririm (1)
b) Ancak bir bölümünü bitiririm (2)
c) Genellikle büyük bir bölümünü bitiririm (3)
d) Çok azını bırakırım (4)
e) Işte kalıp bitirmeye çalışınm (5)

3- "Bazı iş arkadaşlanmla, astlanmla çalışmak güçtür". Bu ifadeye ne derece katıliyorsunuz?
a) Çoğunlukla çok fazla güç bulurum (5)
b) Çok güç bulurum (4)
c) Bazen güç bulurum (3)
d) Çok az gụ̧̈ bulurum (1)
e) Çok olumlu bulurum (1)

4- "Işimle ilgili yeni sorumluluklar çıktığında bu sorumluluklan diğer çalışanlara devretmek yerine kendim üstlenirim". Bu ifadeye ne düzeyde katılıyorsunuz?
a) Kesinlikle katılıyorum (5)
b) Çoğunlukla katılıyorum (4)
c) Bazen katıliyorum (3)
d) Çok az katıliyorum (2)
e) Hiç katılmiyorum (1)

5- "Işimde çok az çeşitlilik ve sorun vardır". Bu ifadeye ne derece katılıyorsunuz?
a) Tamamiyla doğru (5)
b) Çoğu zaman doğru (4)
c) Zaman zaman doğru (3)
d) Nadiren doğru (2)
e) Hiç doğru değil (1) 
6- "Işimin geneklerini yerine getirmek için çoğunlukla aşırı yüklenirim". Bu ifadeye ne derece kathliyorsunuz?
a) Tamamiyla katıliyorum (5)
b) Çŏ̆u zaman doğru (4)
c) Bazen (zaman zaman) doğru (3)
d) Nadiren doğru (2)
e) Kesinlikle doğru (1)

7- "İşimde baskı altında kaldığımda kontrolümü kaybetme eğilimdeyim". Bu ifade sizin için ne derece doğrudur?
a) Tamamıla katılıyorum (5)
b) Çoğu zaman doğru (4)
c) Zaman zaman doğru (3)
d) Nadiren doğru (2)
e) Kesinlikle doğru değil (1)

8- "Işimi gereklerini yerine getirmemi engelleyen birçok müdahalelerin sıkıntısını yaşıyorum".
a) Tamamila katılıyorum (5)
b) Çoğu zaman doğru (4)
c) Zaman zaman doğru (3)
d) Nadiren doğru (2)
e) Hiç doğru değil(1)

9- "Hem mükemmel bir yönetici, hem mükemmel bir eş, hem de bir ebeveyn olmak benim için çok önemlidir". Bu ifadeye ne derece katılıyorsunuz?
a) Tamamiyla katılıyorum (5)
b) Çoğu zaman kathlıyorum (4)
c) Zaman zaman katıliyorum (3)
d) Nadiren katıliyorum (2)
e) Hiçbir zaman katılmıyorum (1)

10- "Işsim evde de devam eder, işimi bitirmeden hayatta uyuyamam". Yukandaki ifade sizin için ne derece doğrudur?
a) Tamamıla katıliyorum (5)
b) Çoğu zaman doğru (4)
c) Zaman zaman doğru (3)
d) Nadiren doğru (2)
c) Hiç doğru değil (1) 


\section{EK-B \\ KIŞílLIK ÖZELLİĞi TANIMA TESTI}

1 Randevular konusunda titiz değilim 12345678 Asla geç kalmam

1 Rekabetçi değilim

12345678 Çok rekabetçiyim

1 Baskı altında bile kendimi asla acele içinde hissetmem

$\begin{array}{llllllll}1 & 2 & 3 & 4 & 5 & 6 & 78 & \text { Kendimi her zaman acele }\end{array}$ içinde hissederim

1 Bir zaman zarfinda her şeyi

12345678 Bir kerede birçok şeyi ele alırım yapmayı denerim daha sonra ne yapacağımı düşünürüm

1 Birşeyi yavaş̧a yaparım

12345678 Birşeyi hızh yaparım

1 Duygulanmı ifade ederim

12345678 Duygulanmı saklanm

1 Birçok ilgim vardır

$\begin{array}{lllllll}1 & 2 & 3 & 4 & 5 & & \end{array}$ İş dışında çok az ilgim vardır

Sayın yönetici, yukarıdaki ifadelerden hangi taraftaki numara sizin durumunuzu ifade ediyorsa onu daire içine alınz. 


\section{Kaynakça}

AKTAS, Allye/AKTAS, Ramazan (1992), "I\$ Stresl," Milli Prodūktivite Dergisi, MPM yayın 1: 153-171.

AKTAŞ. Aliye (2001). "Úst ve Otta Düzey Yöneticilerde Is Stresi," KHO Dergisi.

ARIKAN, Cigdem/AKTAŞ, Allye, "KIşilik Ozellikleri lle Aile ve Gevre Yoşantsısınn Kalp Hastalı̆ğnın Oluşumuna Etkısi," XXN. Ulusal Psikiyatri ve Nörolojik Bilimler Kongresi (Ankara: GATA): 725-726.

ARCHES, Joan (1991), "Social Structure, Bumout and Job Satisfoction," Social Work, 36/3 May.

EROL. V. (1988). Is Tatmini ve Ongülsel Bağhllık (Yayınlanmamuş Yüksek Lisans Tezl, Marmara Úniversitesi Sosyal Bilimler Enstitisu, lstanbul).

GÖDElEK, Ertugrnul (1988), Oç Farklt Is Kolunun (Tekstil, Boya, Çimento) Psikososyal Stres Faktórieri Yơnünden Karşlaşuniması (Yayınlanmiamı̧ Doktora Tezi, Ankara Oniversitesi Sosyal Bilimler Enstitüsu, Ankara).

IŞIKHAN. Vedat (1988). Sosyal Hïnet ve Sag̈lk Alanunda Göreu Yapan Yōneticileri Etkileyen Iș Stres Faktörteri (Yayınlanmomış Doktoro Tezi, H.Ŭ. Sosyal Bilimler Enstitüsü, Ankara).

KŐSE, Sevin̨̧ (1985), 'Endūstri Alanında Stres Yaratan Ögeler.' III. Ullusal Psikoloji Kongresi Bilimsel Calısmalan, (Ankara: Psikoloji Demegil Yaysnlan): 315.321.

OUICK, C. Jones/OUICK D. (1984), Organizational Stress and Preventive Management (New York: Mc Grow Hill Book): 13-170.

SELYE, Hans (1974), Stress Without Disstress (New York: J.B. Lippencott Com) ): 26-39. 